\title{
Kesesuaian Zonasi Pulau-Pulau Kecil : Studi Kasus Kawasan Konservasi Gili Sulat Gili Lawang Lombok Indonesia
}

\author{
Suitability of Small Islands Zoning: A Case Study of the Gili Sulat Gili \\ Lawang Conservation Area, Lombok Indonesia
}

\author{
Sitti Hilyana*, Sadikin Amir, Saptono Waspodo \\ Marine Science Study Program, Faculty of Agriculture, UniversitasMataram, \\ Kota Mataram 83115, Indonesia \\ *corresponding author,email: sittihilyana@gmail.com
}

Manuscript received: 15-18-2020. Accepted: 27-11-2020

\begin{abstract}
ABSTRAK
Gili Sulat Gili Lawang merupakan Pulau-Pulau Kecil yang memiliki keanekaragaman hayati laut yang tinggi dan telah ditetapkan sebagai Taman Wisata Perairan (TWP) seluas 10.000 hektar. Penelitian bertujuan untuk menganalisis kesesuaian zonasi dan analisis pemanfaatan ruang setiap zona. Pengumpulan data dilakukan dengan teknik wawancara secara terstruktur menggunakan kuesioner dan pendekatan Focus Group Discussion (FGD). Analisis kesesuaian zonasi menggunakan Geographic Information System (GIS) analysis Hasil penelitian menunjukkan bahwa kondisi ekosistem mangrove, ekosistem terumbu karang dan ekosistem lamun termasuk kategori buruk sampai dengan baik. Berdasarkan analisis kesesuaian zonasi 193.83 hektar (44.02\%) dari luas terumbu karang sesuai untuk zona inti, 143.33 hektar (32.55\%) terdiri dari 108 hektar ekosistem terumbu karang dan 35.43 hektar ekosistem lamun sesuai untuk zona pemanfaatan terbatas, dan 9,666.47 hektar sesuai untuk zona lainnya yang terdiri dari zona rehabilitasi terumbu karang seluas 93.11 hektar, zona perlindungan 93.11 hektar dan perairan lain 8,585.76 hektar.
\end{abstract}

Kata kunci : ekosistim; informasi; mangrove; rehabilitasi; zonasi

\begin{abstract}
Gili Sulat Gili Lawang are small islands that have high marine biodiversity and have been designated as a Marine Tourism Park (TWP) covering an area of 10,000 hectares. This study aims to analyze the suitability of zoning and analysis of space use in each zone. The data was collected by using a structured interview technique using a questionnaire and Focus Group Discussion (FGD) approach. Zoning suitability analysis used a Geographic Information System (GIS). The assessment showed that the conditions of the mangrove ecosystem, coral reef ecosystem and seagrass ecosystem were in the bad to good categories. Based on the zoning suitability analysis of 193.83 hectares $(44.02 \%)$ of the coral reef area suitable for the core zone, 143.33 hectares $(32.55 \%)$ consists of 108 hectares of coral reef ecosystems and 35.43 hectares of seagrass ecosystems suitable for the zone. limited use, and 9,666.47 hectares are suitable for other zones consisting of a coral reef rehabilitation zone
\end{abstract}


covering an area of 93.11 hectares, a protection zone of 93.11 hectares and other waters $8,585.76$ hectares.

Keywords: ecosystem; information; mangroves; rehabilitation; zoning

\section{PENDAHULUAN}

Taman Wisata Perairan Daerah Gili Sulat Gili Lawang (TWP G. Sulat-G. Lawang) merupakan pulau pulau kecil tak berpenghuni yang telah ditetapkan sebagai Taman Wisata Perairan. TWP G. Sulat-G. Lawang sebagai bagian dari kawasan Lesser Sunda memiliki ekosistem yang unik karena keberadaan tiga ekosistem pesisir utama yaitu ekosistem mangrove, ekosistem lamun dan ekosistem terumbu karang. Ekosistem mangrove di G. Sulat seluas 641.630 ha, dan di G. Lawang seluas 369.023 ha. Luas terumbu karang di G. Sulat 178.688 ha dan di G.Lawang 181.254 ha, sedangkan luas ekosistem lamun di G. Sulat 47.599 ha dan di G. Lawang 35.682 ha. Kondisi perairan laut yang relative baik keanekaragaman hayati laut dengan endemitas biota yang tinggi, bentang alam yang indah, serta letak geografis yang strategis menjadikan G. Sulat-G. Lawang berpotensi untuk pengembangan perikanan dan ekowisata, sehingga dapat dijadikan sebagai sumber mata pencaharian masyarakat.

Permasalahan TWP G.Sulat-G.Lawang adalah belum optimal dan tumpang tindihnya arah pemanfaatan kawasan. Disisi lain penataan sub zona didasarkan pada pertimbangan ekologi, tanpa pertimbangan ekonomi dan sosial, akibatnya pengelolaan TWP G. SulatG.Lawang belum optimal karena masyarakat secara turun temurun menggantungkan hidupnya pada sumberdaya dalam kawasan jauh sebelum kawasan tersebut ditetapkan sebagai hutan lindung maupun sebagai TWP. Kondisi ini tidak sejalan dengan Undang Undang no 27 tahun 2017, bahwa dalam menetapkan suatu kawasan sebagai kawasan konservasi dilakukan berdasarkan pada tujuan pembentukan kawasan konservasi, nilai kepentingan konservasi pada level ekosistem dan level jenis, nilai kepentingan sosial, ekonomi dan budaya serta tingkat luasan kawasan konservasi dalam melindungi plasma nutfah dan interkoneksitas ekologis dari populasi, spesies dan komunitas.

Regulasi PP No. 60 Tahun 2007 sinergis dengan PP 28 tahun 2018 tentang Pengelolaan Konservasi Perairan memberikan peluang dan dukungan secara politik pada setiap daerah untuk memperbaiki pengelolaan kawasan konservasi yang telah ada. Berkaitan dengan adanya kewenangan dua sektor dalam pengelolaan kawasan tersebut, maka dalam pengembangan TWP G. Sulat-G. Lawang memerlukan disain pengelolaan secara terintegrasi. Disamping itu perlu evaluasi penetapan sub zona berdasarkan kriteria kesesuaian ekologi, ekonomi dan sosial. Model pengelolaan diarahkan pada pengelolaan berbasis kesesuaian dan daya dukung Oleh karena itu dalam mengimplementasikan konsep tersebut perlu diawali kajian ilmiah tentang optimasi pemanfaatan ruang TWP G. Sulat-G. Lawang Kabupaten Lombok Timur.

Mengingat permasalahan pengelolaan TWP G. Sulat-G. Lawang yang multiuse, disisi lain masyarakat selama bertahun-tahun dan turun temurun merupakan sumber mata pencaharian utama, sementara kepentingan Pemeritah Daerah yang tertuang dalam RZWP3K (Rencana Zonasi Wilayah Pesisir dan Pulau-Pulau Kecil) tertuang dalam 
dokumen Perda no 12 tahun 2017 sebagai kawasan konservasi TWP yang mengarah pada kepentingan wisata, maka perlu dilakukan penataan sub zona dengan mempertimbangkan berbagai kriteria ekologi, ekonomi dan sosial sebagaimana diatur dalam Permen Nomor 17 tahun 2008 sebagai turunan UU 27 tahun 2007 tentang kawasan konservasi perairan. Sedangkan untuk mendukung pemanfaatan ruang kawasan yang paling optimal, perlu dilakukan analisis kesesuaian lahan dan daya dukung kawasan. Sebagai konsekuensi dari kawasan konservasi, maka setiap aktivitas yang akan dikembangkan harus berbasis konservasi dan daya dukung kawasan sehingga secara ekologis kualitas sumberdaya dapat terjaga keberlanjutannya, disamping memberikan kontribusi income yang menguntungkan serta dapat menjamin peningkatan kesejahteraan masyarakat secara sosial. Untuk menuju pada pengelolaan TWP G. Sulat-G. Lawang berbasis kesesuaian zonasi, maka penelitian ditujukan untuk menganalisis kesesuaian sub zona dengan mempertimbangkan kriteria kesesuaian kawasan konservasi perairan.

\section{METODOLOGI PENELITIAN}

Penelitian dilaksanakan pada bulan Mei sampai September 2019 di TWP G.Sulat G.Lawang Kabupaten Lombok Timur. Data biofisik diperoleh dengan visual survey dan pengukuran langsung. Pengumpulan data sekunder dari berbagai sumber yang relevan, dipilih secara terstruktur dari instansi terkait. Data fisik mangrove dilakukan menggunakan metode Transek-kuadrat berdasarkan perbedaan struktur vegetasi (Bengen, 2001). Data lamun menggunkaan metode Sistematik Random Sampling, sedangkan data terumbu karang menggunakan Metode Transek Garis untuk melihat tutupan life form karang. Data sosial ekonomi menggunakan metode survei melalui teknik wawancara dengan pertanyaan terstruktur (kuisioner). Pengambilan contoh menggunakan metode acak berlapis/stratifikasi, dari populasi yang telah disekat menjadi beberapa kelompok, setiap kelompok dilakukan dengan metode acak sederhana (Bengen, 2000). Analisis Kesesuaian Kriteria TWP, menggunakan kriteria modifikasi Salm, 1984 dan Yulianda 2006. Analisis kesesuian zona, dengan bantuan GIS menggunakan software Arc Gis ver.9.

\section{HASIL DAN PEMBAHASAN}

Hasil analisis identifikasi kondisi eksisting menunjukkan ekosistem mangrove di TWP Gili Sulat - Gili Lawang termasuk kategori baik dengan persen penutupan $>70 \%$ dan kerapatan pohon $>1100$ vegetasi per hektar. Kondisi terumbu karang termasuk kategori sedang dengan persen penutupan karang antara 28-58\%, karakteristik dasar perairan dengan rataan terumbu cukup panjang (>50 -100 meter),sedangkan ekosistem padang lamun termasuk kategori kurang sehat karena persen penutupan lamun antara 32 - $60 \%$

Penataan zonasi TWP G.Sulat-G.Lawang didasarkan pada kebutuhan pengelolaan TWP G.Sulat-G.Lawang secara. Zonasi dilakukan dengan menggunakan persentase total nilai skoring kriteria pengelolaan TWP. Persentase total nilai skoring diperoleh dengan membandingkan total nilai skoring masing-masing keriteria dengan total nilai skor keseluruhan dikali 100 persen. Dengan menggunakan teknik interval skor, zonasi peruntukan kawasan dibagi atas tiga (3) zona yaitu : 
1. Zona inti memiliki interval nilai persentase skor sebesar $\geq 80 \%$ berada pada stasiun Poto Gili, stasiun Pondok Kecil, stasiun Pegatan I, stasiun Landi dan stasiun Tanjak Mukur dengan luas 193.83 hektar atau $44.02 \%$ dari luas terumbu karang dan lamun yang ada didalam kawasan.

2. Zona Pemanfaatan Terbatas memiliki interval nilai persentase antara $68-80 \%$ berada pada stasiun Pondok Jaya, Selang, Batu Mandi I, Batu Mandi II, Menanga Kapal, Pegatan II, Luar Gili I, Luar Gili II, Luar Gili III dan Kampir Bier dengan luas 143.33 atau $32.55 \%$ terdiri dari 108 hektar terumbu karang dan 35.43 hektar lamun.

3. Zona Lainnya memiliki interval nilai persentase $<67$ berada pada stasiun Luar Gili, stasiun Pekaje, stasiun Menanga Todak, stasiun Luar Gili IV dan stasiun Panaean dengan luas 9,662.84 terdiri dari zona rehabilitasi terumbu karang 93.11 hektar dan perairan lainnya $9,569.73$ hektar.

Kawasan mangrove seluas 1.010,65 diarahkan pada zona perlindungan 987,6 hektar dan pemanfaatan terbatas untuk kegiatan wisata mangrove seluas 23,05 hektar untuk lokasi penataan walkboad di dalam kawasan mangrove.

\section{Analisis Kesesuaian dan Daya Dukung Lahan}

\section{Pemanfaatan Perikanan Karang}

Hasil analisis kesesuaian diperoleh ruang dengan tigaa kelas kesesuian, yaitu status sesuai seluas 262.83 hektar, sesuai bersyarat seluas 93.11 hektar, dan tidak sesuai seluas 42.71 hektar. Potensi ikan terumbu karang dapat mencapai 10-30 ton $/ \mathrm{km}^{2} /$ tahun (Yulianda et al. 2009). Dengan kondisi tutupan karang yang mencapai rata-rata $70 \%$ dengan luas kesesuaian untuk perikanan karang seluas 108 hektar atau $1.08 \mathrm{~km}^{2}$, berdasarkan dugaan tersebut, maka ikan karang yang dapat diperoleh berdasarkan daya dukung karang $(0.7$ x 108 ha $=75.6$ hektar) atau $0.756 \mathrm{~km}^{2}$ adalah sebesar $15.120 \mathrm{~kg} /$ tahun. Apabila nelayan dalam satu bulan menangkap ikan selama 14 hari, maka rata-rata ikan yang boleh ditangkap adalah $90 \mathrm{~kg} / \mathrm{hari}$.

\section{Pemanfaatan Wisata Selam}

Hasil analisis bahwa untuk pengembangan wisata selam diperoleh luasan ruang dengan 3 (tiga) kelas kesesuaian meliputi kelas sesuai seluas 262.83 hektar, sesuai bersyarat seluas 93.11 hektar dan tidak sesuai seluas 42,71 hektar. Ruang dengan kategori sesuai bersyarat dialokasikan untuk zona rehabilitasi sekaligus untuk wisata snorkeling disebabkan karena kerusakan karang akibat aktivitas pemanfaatan areal dengan menggunakan bom, sehingga tutupan karang menjadi relatif kecil $(<30 \%)$.

Peraturan Pemerintah Nomor 18 Tahun 1994 tentang pengusahaan ekowisata di zona pemanfaatan taman nasional dan taman wisata alam, maka areal yang diizinkan untuk dikelola yakni 10\% dari luas zona pemanfaatan, sehingga luasan yang dapat dimanfaatkan untuk wisata selam adalah seluas 10.8 hektar. Berdasarkan Yulianda (2007), bahwa wisata selam harus mempertimbangkan kondisi komunitas terumbu karang, karena persen tutupan karang menggambarkan tingkat kesehatan dan daya dukung karang. Jika kondisi terumbu karang memiliki tutupan $70 \%$, maka luas areal selam di areal terumbu karang yang dapat 
dimanfaatkan sebesar $70 \%$ dari luas hamparan. Dengan demikian daya dukung karang untuk wisata selam di TWP G. Sulat-G. Lawang sebesar 7.5 hektar, sehingga jumlah kunjungan wisatawan penyelam yang dapat ditolerir berdasarkan perhitungan pendekatan daya dukung kawasan sebesar 150 orang/hari.

\section{Pemanfaatan Wisata Mangrove}

Hasil analsis kesesuaian untuk wisata mangrove diperoleh ruang dengan 3 (tiga) kategori kesesuaian yaitu kelas sesuai seluas 966.85 hektar, kelas sesuai bersyarat 54.20 hektar dan tidak sesuai seluas 101.74 hektar. Mengacu pada Peraturan Pemerintah Nomor 18 Tahun 1994, maka areal mangrove yang dapat dimanfaatkan untuk wisata adalah 10 persen, sehingga luas mangrove yang direkomendasikan untuk kegiatan wisata 96.68 ha. Untuk memudahkan kegiatan wisata mangrove dibutuhkan sarana walkboad didalam kawasan berupa jembatan kayu sehingga wisatawan dapat menikmati keindahan ekosistem mangrove di kedua pulau dengan panjang masing-masing di G. Lawang $9.283 \mathrm{~km}$ dan di G. Sulat $13.765 \mathrm{~km}$, maka jumlah kunjungan yang dapat ditolerir sejumlah 230 orang/hari dengan asumsi setiap 1 orang memutuhkan $100 \mathrm{~m}$ sarana walkboad.

\section{Optimasi Pemanfaatan Ruang G.Sulat-G.Lawang}

Penentuan luasan optimal dalam pemanfaatan kawasan konservasi G.SulatG.Lawang untuk kegiatan perikanan karang dan ekowisata bahari menggunakan analisis spasial dinamik. Analisis dinamik bertujuan untuk mengalokasikan pemanfaan lahan yang paling optimal secara spasial sehingga pengelolaan sumberdaya dapat berkelanjutan dengan mempertimbangkan aspek ekologi, ekonomi dan sosial. Analisis ini menggunakan pembobotan nilai dari kriteria yang paling sesuai. Nilai bobot dari masing-masing kriteria dan sub kriteria merupakan input nilai berdasarkan hasil kajian yang digunakan dalam penentuan kebijakan pengelolaan kawasan G. Sulat-G. Lawang.

Fokus analisis dalam penelitian adalah : penangkapan ikan karang, wisata selam, wisata snorkeling dan wisata mangrove dengan variabel (a) luas lahan maksimun, (b) tingkat produksi atau kunjungan berdasarkan kemampuan daya dukung lingkungan, (c) kemampuan penyerapan tenaga kerja, dan (d) peningkatan hasil produksi (penerimaan) dari pemanfaatan lahan. Berdasarkan karakteristik ekologi perairan terkait dengan kondisi ekosistem terumbu karang, mangrove, lamun dan kualitas perairan laut serta karakteristik sosial ekonomi dan budaya serta kelembagaan menunjukkan bahwa kawasan TWP G. Sulat-G. Lawang memiliki potensi besar untuk pengembangan kegiatan perikanan dan ekowisata. Berdasarkan analisis kesesuaian lahan dan perhitungan daya dukung, luas pemanfaatan optimal yang dapat dialokasikan untuk kegiatan seperti pada Tabel 1. 
Tabel 1. Luas Pemanfaatan Optimal Kawasan G.Sulat-G.Lawang

\begin{tabular}{ccc}
\hline $\begin{array}{c}\text { Kesesuaian Lahan kawasan } \\
\text { konservasi laut }\end{array}$ & Luas Area (ha) & Persentase (\%) \\
\hline Zona inti & 193.83 & 1.94 \\
\hline Zona Pemanfaatan Terbatas & 9.80 & 0.11 \\
- Wisata selam & 9.30 & 0.09 \\
- Wisata Snorkeling & 23.40 & 0.24 \\
- Wisata Mangrove & 97.20 & 0.97 \\
- Perikanan Karang & & \\
\hline Zona Lainnya & 987.60 & 9.87 \\
- Zona Perlindungan & 93.11 & 0.93 \\
- Zona Rehabilitasi & $8,585.76$ & 85.85 \\
- Perairan lain & 10.000 & 100.00 \\
\hline \multicolumn{2}{c}{ Total } & \\
\hline
\end{tabular}

Sumber : hasil olah data primer, 2019

Pemanfaatan TWP G. Sulat-G. Lawang untuk kegiatan perikanan karang dan ekowisata bahari sangat penting dalam menentukan optimasi pemanfaatan kawasan. Pemanfaatan kawasan dengan beberapa dimensi diharapkan dapat menyerap tenaga kerja dan meningkatkan kesejahteraan. Oleh karena itu penentuan alokasi pemanfaatan kawasan harus didasarkan pada (1) kesesuaian lahan; (2) daya dukung lingkungan dan informasi ilmiah sebagai acuan dalam memformulasi kebijakan penatakelolaan kawasan yang dapat dipertanggungjawabkan. Argumentasi ini membutuhkan implikasi nyata dalam bentuk interaksi melalui koordinasi, kerjasama dan komitmen para pemangku kepentingan, menuju kearah penataan ruang kawasan yang optimal. Interaksi antara sektor publik dan swasta sangat diperlukan untuk memecahkan persoalan masyarakat dan menciptakan kesempatan sosial (Kooiman et al, 2005 dalam Adrianto 2006).

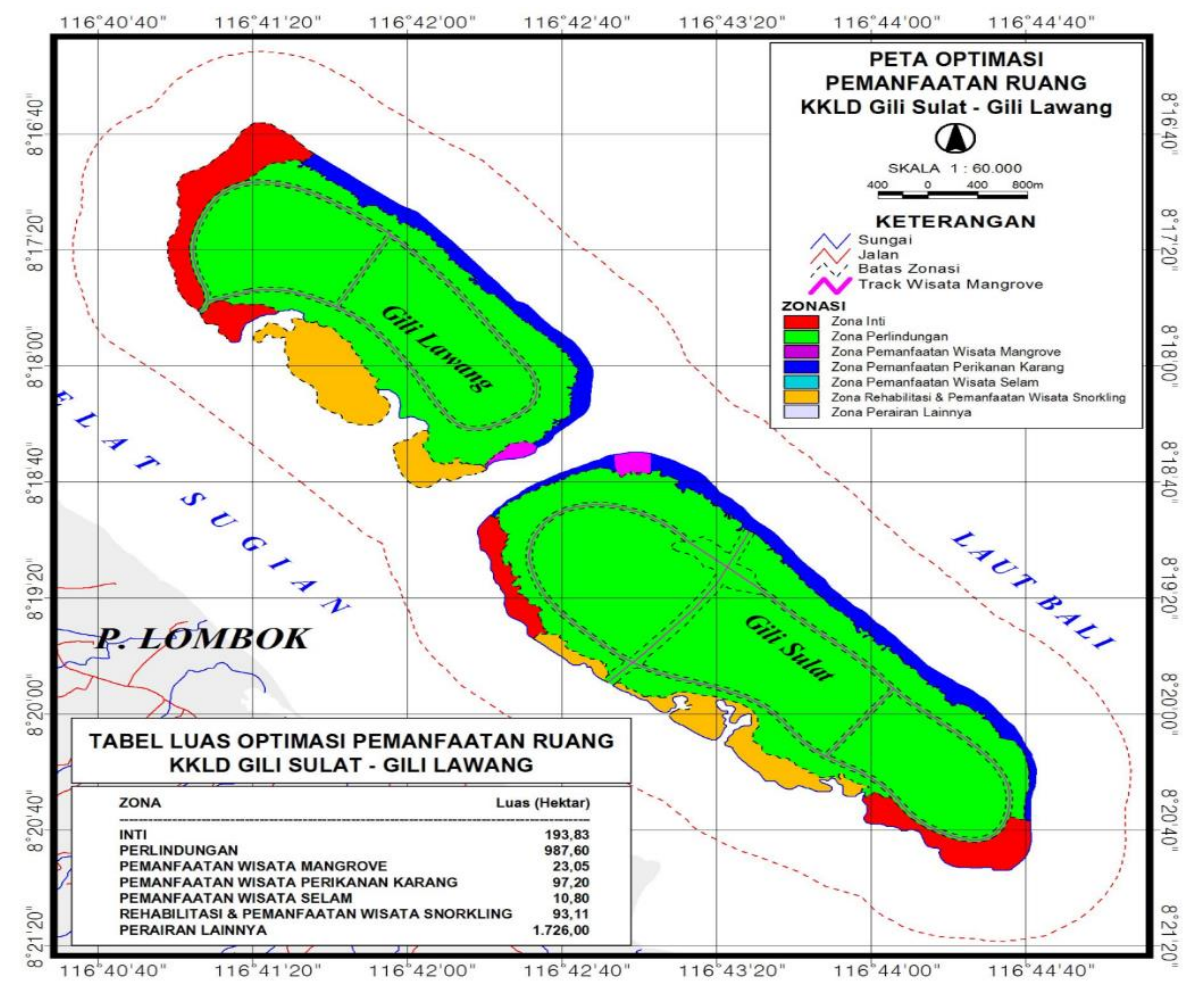

Gambar 1. Zonasi pemanfaatan ruang TWP G.Sulat-G.Lawang 


\section{Optimasi Pemanfaatan Perikanan Karang}

Pengembangan perikanan karang didasarkan pada analisis kondisi terumbu karang dan karakteristik lingkungan perairan. Indikator karakteristik lingkungan perairan yang dianalisis adalah persyaratan optimum pertumbuhan karang, hal ini akan memberikan gambaran bahwa lokasi tersebut potensial bagi pengembangan perikanan karang. Atas dasar itu pelestarian sumberdaya karang dalam bentuk konservasi terumbu karang sangat penting dilakukan. Alasan ini didukung hasil penelitian Arifin, 2008 bahwa pada kondisi tidak ditetapkan kawasan konservasi laut, nilai produksi optimal sebesar 21.85 ribu ton, effort optimal 2,809.29 trip dan rente optimalnya sebesar Rp. 74.28 milyar lebih rendah dibandingkan pada kondisi sebagai kawasan konservasi dengan berbagai luasan.

Selain alasan ekonomi tujuan perlindungan terumbu karang adalah (1) memelihara fungsi ekologis dengan melindungi habitat tempat hidup, bertelur, dan memijah biota-biota laut, dan (2) memelihara fungsi ekonomis kawasan pesisir bagi masyarakat sekitar, sehingga terjadi keberlanjutan dan produksi perikanan yang pada akhirnya akan meningkatkan pendapatan, baik dari produksi perikanan maupun dari 208ector pariwisata bahari. Menurut Westmacott et al 2000, kawasan konservasi memegang peranan penting bagi pelestarian dan pengelolaan dengan cara: (a) melindungi daerah terumbu karang yang tidak rusak dan dapat menjadi sumber larva serta sebagai alat untuk membantu pemulihan, (b) melindungi daerah yang bebas dari dampak manusia dan cocok sebagai substrat bagi penempelan karang dan pertumbuhan kembali, dan (c) memastikan bahwa terumbu karang tetap menopang kelangsungan kebutuhan masyarakat sekitar yang bergantung padanya.

Hasil penelitian Hutomo dan Suharti (1998), melaporkan bahwa terumbu karang dapat memberikan manfaat langsung berupa hasil laut sebanyak 25 ton/ha/tahun. Berdasarkan hal tersebut, bahwa kawasan konservasi laut dapat meningkatkan produksi hasil tangkapan yang pada akhirnya dapat meningkatkan pendapatan nelayan sekitar ekosistem terumbu karang. Bila diasumsikan jumlah tersebut konstan per tahun dengan harga rata-rata ikan di daerah studi sebesar Rp. 30,000/kg, maka diperoleh manfaat terumbu karang di kawasan G. Sulat-G. Lawang bagi perikanan sebesar Rp. 750,000,000/ha/tahun.

Potensi ikan terumbu karang dapat mencapai 10-30 ton/ $/ \mathrm{km}^{2} /$ tahun (Yulianda et al. 2009). Dengan kondisi tutupan karang yang mencapai rata-rata $70 \%$ dengan luas kesesuaian untuk perikanan karang seluas 108 hektar, maka berdasarkan asumsi tersebut, ikan karang yang dapat diperoleh berdasarkan daya dukung karang 75.6 hektar atau $0.756 \mathrm{~km}^{2}$ adalah sebesar $15.120 \mathrm{~kg} / \mathrm{tahun}$. Apabila harga nelayan Rp 30,000/kg, maka nilai hasil tangkap sebesar Rp 453,600,000/tahun.

\section{Optimasi Pemanfaatan Wisata Selam}

Pariwisata bahari adalah kegiatan rekreasi seperti berenang, berselancar, berjemur, menyelam, berdayung, snorkling dan menikmati keindahan pesisir (Dahuri, 1993). Kegiatan wisata bahari yang dapat dilakukan di kawasan konservasi Gili Sulat-Gili Lawang adalah menyelam. Daya tarik dari kegiatan ini adalah kondisi terumbu karang yang masih relatif baik dan keberadaan ikan karang dengan berbagai jenis pada stasiun-stasiun tertentu. Pada stasiun lainnya menunjukkan mulai terjadinya pemutihan karang. Luas lahan yang sesuai 
untuk wisata selam sebesar 108 hektar, terdiri dari 54 hektar di kawasan perairan Gili Lawang dengan titik spot di stasiun Batu Mandi I, Batu Mandi II dan Menaga Kapal. Sedangkan lokasi di kawasan perairan Gili Sulat seluas 54 hektar dengan titik spot di stasiun Gili Luar I, Gili Luar II dan Gili Luar III. Pembobotan kesesuaian perairan untuk wisata selam dilakukan dengan mempertimbangkan faktor pembatas yang terdiri dari kecerahan perairan, kecepatan arus, kedalaman perairan, dan penutupan karang hidup.

Di kawasan ini terdapat sekitar 10 (sepuluh) titik lokasi tujuan wisata selam dan mangrove, sebagai fungsi konservasi, G. Sulat-G. Lawang merupakan salah satu kawasan yang memiliki tingkat biodiversity tinggi. Untuk pemanfaatan wisata selam dapat dilakukan pada beberapa spot dengan kategori sesuai bersyarat, hal ini berarti bahwa ada beberapa lokasi terumbu karang yang memerlukan perlakuan tertentu terhadap persyaratan kesesuaian untuk ditingkatkan levelnya pada kategori sesuai bagi kegiatan wisata selam. Parameter pembatas diberi pembobotan dan skor didasarkan pada tingkat kepentingan untuk kegiatan selam. Parameter kecerahan perairan dan kecepatan arus memiliki bobot tertinggi karena faktor kecerahan dan kecepatan arus sangat menentukan kesesuaian bagi kegiatan wisata selam, maupun untuk pertumbuhan terumbu karang, sedangkan penutupan karang hidup merupakan daya tarik wisatawan untuk menikmati keindahan bawah laut.

Perairan yang jernih mengundang rasa ingin tahu untuk melihat keindahan bawah laut, dan kecepatan arus merupakan faktor yang berhubungan dengan keselamatan penyelam. Kedalaman dasar laut, menempati bobot yang lebih kecil daripada lainnya, karena parameter kedalaman dapat teratasi oleh parameter lainnya. Kondisi terumbu karang di kawasan G. Sulat-G. Lawang tergolong pada 3 kelas yaitu tidak baik, cukup baik dan baik sesuai dengan persen tutupan karang hidup pada masing-masing lokasi. Kecerahan perairan sangat mendukung yaitu hampir mencapai 100\%. Adapun jenis ikan yang ditemukan di sekitar lokasi terumbu karang terdiri ikan indikator seperti famili Chaetodontidae, jenis ikan target seperti dari famili Siganidae, dan jenis ikan mayor seperti dari famili Pomacentridae. Arus pada lokasi ini juga bergerak dengan kecepatan $13 \mathrm{~cm} /$ det sampai $40 \mathrm{~cm} /$ det, dimana kisaran tersebut masih dapat ditoleransi untuk kegiatan ekowisata bahari. Kedalaman perairan berkisar antara 5-20 m walaupun ada beberapa lokasi yang memiliki kedalaman lebih dari $20 \mathrm{~m}$ berdasarkan peta batimetri.

Lokasi dengan kondisi terumbu karang rusak akibat penambangan oleh penduduk seperti yang ada di stasiun Panaean, stasiun Mananga Todak, stasiun Kampar Bear, stasiun Pekaje, stasiun Luar Gili dan stasiun Pondok Jaya. Untuk mengembalikan kondisi terumbu karang pada stasiun tersebut maka diarahkan untuk zona rehabilitasi. Oleh karena itu pemerintah perlu menysun aturan pengelolan kawasan G. Sulat-G. Lawang dengan melibatkan masyarakat untuk berperan aktif dalam menjaga kelestarian sumberdaya dengan tidak melakukan pemboman ikan di daerah terumbu karang.

Berdasarkan penilaian masing-masing parameter yang menentukan kesesuaian wisata selam dengan menggunakan skoring dan pembobotan, dihasilkan pengelompokan kesesuaian lahan untuk ekowisata bahari sebagai berikut: 


\section{a. Sesuai (S1)}

Wilayah dengan kategori "sesuai" tanpa faktor pembatas yang menghambat perlakuan adalah stasiun Selang, Bantu Mandi I, Batu Mandi II, Menanga Kapal (perairan Gili Lawang) dengan persentase skor 82,85. Lokasi stasiun Pegatan II, Luar Gili I, Luar Gili II dan Luar Gili III (perairan Gili Sulat) termasuk kategori sesuai dengan persentase skor 82,85 . Lokasi ini sesuai untuk pengembangan wisata selm, berdasrkan penilaian parameter-parameter yang mendukung seperti: kecerahan yang tinggi, penutupan karang hidup, dan arus yang tidak kuat. Walaupun parameter kesesuaian pada atribut kecepatan arus namun total nilai keseluruhan memberikan gambaran sesuai. Mengingat lokasi-lokasi pada stasiun tesebut memiliki arus yang cukup kuat, maka jenis wisata yang direkomendasikan adalah wisata selam khusus. Parameter-parameter penilaian kelayakan wisata bahari, dibedakan menjadi dua, yaitu: (1) pengaruh manusia, dan (2) tidak dipengaruhi oleh manusia. Parameter yang bisa dipengaruhi oleh manusia, meliputi kecerahan perairan, dan persentase penutupan karang, sedangkan yang relatif sulit dipengaruhi oleh manusia seperti kedalaman perairan dan kecepatan arus.

\section{b. Sesuai Bersyarat (S2)}

Wilayah yang termasuk dalam kategori sesuai bersyarat mempunyai faktor pembatas yang agak serius untuk dijadikan kawasan wisata bahari khususnya kegiatan menyelam. Hasil perhitungan pada Tabel 13, menunjukkan paada lokasi stasiun Pondok Jaga, Luar Gili, Selang, Menanga Todak, Luar Gili IV, Pegatan I, Panaean dan Kampir Bear memperoleh persentase skor berkisar 69,72 sehingga semua lokasi tersebut termasuk kategori Sesuai Bersyarat (S2). Daerah yang termasuk dalam kategori sesuai bersyarat mempunyai faktor pembatas serius untuk pengembangan wisata selam, antara lain penutupan karang tidak memenuhi kriteria untuk kesesuaian wisata selam.

\section{c. Tidak Sesuai $(\mathbf{N})$}

Wilayah yang termasuk dalam kategori ini mempunyai faktor pembatas permanen, semua parameter yang ada memiliki keterbatasan untuk dikembangkan menjadi kawasan wisata selam. Berdasarkan hasil pengamatan, lokasi stasiun Pegatan I termasuk kategori tidak sesuai untuk wisata selam. Kondisi ini dapat difahami karena keberadaan karang di stasiun ini sangat rendah, begitupula dengan tutupan dan jenis karang ada sangat rendah.

\section{Optimasi Pemanfaatan Wisata Mangrove}

Wisata mangrove merupakan aktivitas yang potensial untuk dikembangkan. Berdasarkan parameter kesesuaian untuk pengembangan wisata seperti ketebalan mangrove $>300$ pohon per meter, kerapatan mangrove $>10$ per 100 meter persegi, jenis mangrove $>3$ jenis, jenis biota di bawah tegakan berupa udang, kepiting, moluska serta keberadaan satwa dan reftil di dalam ekosistem mangrove. Disamping parameter ekologis, kesesuaian pengembangan wisata mangrove di G. Sulat-G. Lawang khususnya di stasiun Landi dan stasiun Kampir Bier juga didukung oleh keberadaan infrastruktur untuk kegiatan walkboald atau trecking dalam kawasan berupa jembatan kayu sepanjang 350 meter. Untuk 
mengoptimalkan pemanfaatan wisata mangrove maka penambahan infrastruktur walkboad atau sarana tracking sepanjang 2,304 km mengelilingi kedua pulau. sehingga total kawasan mangrove yang dapat dimanfaatkan untuk wisata mencapai 23.4 hektar. Infrastruktur jembatan ini juga sekaligus sebagai sarana yang dapat dijadikan sebagai akses bagi penyelam yang melakukan aktivitas penyelaman di areal lokasi Selang dan Pegatan II. Dilihat dari luasannya, areal pengembangan wisata mangrove relatif kecil yaitu $3.36 \%$ dari luasan mangrove seluas 1,010.65 hektar, dengan prinsip kehati hatian agar ekosistem dapat berkelanjutan.

TWP G. Sulat-G. Lawang merupakan pulau tak berpenghuni didominasi vegetasi mangrove seluas 641,63 hektar di Gili Sulat dan 369.02 hektar di kawasan Gili Lawang. Beberapa stasiun pengamatan kondisi mangrove mengalami tekanan geomorfologi pantai yang cukup besar, hal ini karena 5-10 tahun yang lalu masyarakat luar kawasan melakukan penebangan di bagian utara pulau karena permasalahan kesulitan pengawasan. Berdasarkan parameter yang menentukan wisata mangrove menggunakan skoring dan pembobotan, dihasilkan pengelompokan kesesuaian wisata mangrove sebagai berikut:

\section{a. Sesuai (S1)}

Wilayah dengan kategori "sesuai" tanpa faktor pembatas yang menghambat perlakuan, berada pada stasiun Selang, Bantu Mandi I , Batu Mandi II, Menanga Kapal (G.Lawang) dengan persentase skor rata-rata 82.85, stasiun Pegatan II, Luar Gili I, Luar Gili II dan Luar Gili III (G.Sulat) termasuk kategori sesuai dengan skor 82.85. Seluruh parameter menunjukkan wilayah ini sangat sesuai untuk pengembangan ekowisata mangrove. Penilaian berdasarkan parameter yang mendukung seperti: ketebalan mangrove, kerapatan, jenis biota, jenis mangrove, tinggi pasut dan jarak dari kawasan lainnya. Parameter penilaian kelayakan wisata bahari, dibedakan menjadi dua, yaitu: (1) pengaruh manusia, dan (2) tidak dipengaruhi oleh manusia. Parameter yang tidak bisa dipengaruhi meliputi tinggi pasut, dan persentase penurupan basal, jensi biota yang mendiami dan jarak dari kawasan lainnya.

\section{b. Sesuai Bersyarat (S2)}

Areal dengan kategori sesuai bersyarat mempunyai faktor pembatas agak serius untuk dijadikan kawasan wisata bahari khususnya kegiatan menyelam. Hasil perhitungan pada Tabel 13, menunjukkan paada lokasi stasiun Batu Mandi , stasiun Mananga Kapal, stasiun Luar Gili I, stasiun Luar Gili II, stasiun Luar Gili III, stasiun PanaeanI, sentase skor berkisar 66,66 sehingga semua lokasi tersebut termasuk kategori Sesuai Bersyarat (S2). Daerah yang termasuk dalam kategori sesuai bersyarat mempunyai faktor pembatas serius untuk pengembangan wisata managrove, antara lain penutupan basal dan kerapatan mangrove kurang memenuhi kriteria untuk kesesuaian wisata mangrove.

\section{c. Tidak Sesuai $(\mathbf{N})$}

Wilayah yang termasuk kategori $\mathrm{N}$ memiliki faktor pembatas permanen, seluruh parameter memiliki keterbatasan untuk dikembangkan menjadi kawasan wisata mangrove. 
Hasil pengamatan, lokasi stasiun Batu Mandi I dan stasiun Luar Gili II termasuk kategori tidak sesuai untuk wisata mangrove, karena keberadaan mangrove di stasiun ini hampir tidak ada berupa tanah rawa terbuka, tidak terdapat keberadaan biota.

Untuk menjaga keberlanjutan produktivitas hutan mangrove maka pemanfaatan harus berbasis pengelolaan yang berkelanjutan dengan mempertimbangkan keragaman aktivitas yang mungkin menggunakan area yang sama atau dalam periode yang berbeda tanpa menyebabkan kerusakan pada sistem. Selain dengan melihat keragaman aktivitas untuk proses produksi, maka pengelolaan kawasan mangrove dapat dilakukan juga dengan membatasi penebangan dan melakukan rehabilitasi mangrove serta edukasi masyarakat terkait pentingnya ekosistem mangrove secara ekologis, ekonomi dan sosial.

Tabel 2. Optimasi Pemanfaatan Ruang Kawasan Gili Sulat-Gili Lawang

\begin{tabular}{clccr}
\hline No & Jenis Pemanfatan & $\begin{array}{c}\text { Produksi } \\
\text { /thn }\end{array}$ & $\begin{array}{c}\text { Harga } \\
(\mathbf{R p})\end{array}$ & Nilai Prod (Rp) \\
\hline 1 & Perikanan Karang & $15,120 \mathrm{~kg}$ & 30,000 & $453,600,000$ \\
\hline 2 & Wisata Selam & 6,900 orang & 500,000 & $3,450,000,000$ \\
\hline 2 & Wisata Snorkeling & 5,520 orang & 300,000 & $1,656,000,000$ \\
\hline 3 & Wisata Mangrove & 10,580 orang & 250,000 & $2,645,000,000$ \\
\hline TotalNilaiProduksi & & & $8,204,600,000$ \\
\hline
\end{tabular}

Sumbet : Data Primer diolah, 2019

Berdasarkan dimensi sosial terkait dengan serapan tenaga kerja, maka pemnanfaatan kawasan pada kondisi optimum berpotensi menyerap tenaga kerja pada kegiatan perikanan karang sebesar 69,600 HOK per tahun, untuk pengembangan ekowisata 49,404 HOK per tahun. Apabila semua jenis pemanfaatan diasumsikan dapat berkembang secara ideal, maka pengelolaan TWP merupakan solusi mengurangi pengangguran atau sebagai mata pencaharian yang menguntungkan, sehingga dapat digunakan sebagai upaya mengurangi kemiskinan masyarakat pesisir khususnya di sekitar kawasan konservasi G. Sulat-G. Lawang. Berdasarkan hasil analisis, bahwa susunan peringkat jenis pemanfaatan TWP G. Sulat-G. Lawang menggunakan dinamik spasial adalah secara berturut-turut adalah wisata selam seluas 10,8 hektar, wisata mangrove seluas 23.40 hektar, dan wisata snorkeling seluas 9,3 ha (dilakukan pada zona rehabilitasi).

Jumlah kunjungan wisatawan rata-rata yang diperbolehkan dalam satu hari berdasarkan daya dukung kawasan 17,526 orang/tahun. Apabila pengeluaran bersedia dibelanjakan oleh wisatawan (WTP) sebesar Rp. 5,200,000/orang, maka total pengeluaran yang dibelanjakan oleh wisatawan untuk menunju lokasi wisata adalah $\mathrm{Rp}$. 91,135,200,000/tahun. Apabila dikaitkan dengan nilai manfaat ekonomi ekologi dari sumberdaya terumbu karang dan mangrove yang ada di kawasan G. Sulat-G. Lawang sebesar Rp 2,311,366,407/tahun, maka pengembangan wisata bahari dikawasan G. Sulat-G. Lawang layak untuk dikembangkan.

Davis and Tisdell (1996), nilai daya dukung ekonomi suatu kawasan konservasi dapat ditingkatkan melalui pengelolaan yang optimal dan peningkatan pengetahuan tentang 
ekowisata bahari terutama wisata selam, distribusi dan rotasi setiap penyelaman, pengaturan ruang dan waktu bagi snorkeler dan fotografer bawah laut. Diharapkan pemahaman ini dapat meminimalisir kerusakan karang. Kombinasi keduanya diharapkan dapat meningkatkan eksistensi obyek wisata dan menghasilkan nilai ekonomi yang tinggi.

Terumbu karang sebagai salah satu ekosistem pesisir mempunyai nilai manfaat yang sangat signifikan, ditinjau dari aspek ekologi maupun ekonomi. Terumbu karang menyumbang hasil perikanan laut kurang lebih 10-15\% dari total produksi. Hasil penelitian Husni (2001), nilai ekonomi terumbu karang untuk perikanan di Kawasan Gili Indah Kabupaten Lombok Barat-NTB adalah $611.34 \mathrm{~kg} / \mathrm{ha} / \mathrm{tahun}$ dengan nilai Rp. 48,731,275/ha/tahun, sedangkan nilai ekonomi untuk ekowisata bahari Rp. 69117180.36. Hasil penelitian yang serupa dilakukan oleh Wawo (2000) di Pulau Nusa Laut Maluku, bahwa nilai ekonomi terumbu karang adalah $\mathrm{Rp} 4,265,174 /$ ha/tahun. White dan Trinidad (1998) di Philipina sebesar US \$ 319-1,300 (Rp 3,658,930-14,911,000,-/ha/tahun), serta penelitian Dahuri (1999) di Kawasan Barelang dan Bintan Rp 1,614,637,864 /ha/tahun.

Fringing reef merupakan pelindung pantai dari terpaan gelombang, sehingga stabilitas pantai tetap terjaga. Hiew dan Lim (1998), menyatakan bahwa nilai terumbu karang per hektar per tahun sebagai pencegah erosi sebesar US\$ 34,871.75 atau dengan asumsi US\$ 1 setara dengan Rp. 14,500 maka nilai fungsi terumbu karang sebagai pencegah erosi sebesar Rp. 505,629,500/ha/tahun. Di samping itu nilai keindahan, kekayaan biologi sebagai bagian dari suksesi alam dalam menjaga kelangsungan kehidupan dalam perannya sebagai sumber plasma nutfah, membuat terumbu karang menjadi kawasan ekosistem pesisir yang sangat penting dari berbagai segi (Garces, 1992). Ruitenbeek (2001), menyatakan bahwa nilai fungsi tidak langsung terumbu karang sebagai penyedia biodiversity sebesar US\$ 15,000/ha/tahun atau Rp. 217,500,000

Terumbu karang juga berperan dalam proses transport nutrien baik organik maupun anorganik diantara dua ekosistem pesisir (Clark, 1996). Fungsi fisik terumbu karang lainnya menururt Baker dan Kaeoniam (1986), sebagai filter untuk menjaga kualitas air. Selain sebagai peredam gelombang, perlindungan alamiah terhadap daratan yang berhadapan dengannya meminimalkan abrasi serta penghasil pasir putih bagi kawasan pantai yang berhadapan.

Nilai ekonomi terumbu karang di Selat Lembeh dilaporkan oleh Parwinia (2006), yaitu nilai ekonomi ekstratif dengan indikator total revenue dari perikanan berkisar antara Rp. 27,000,000 - Rp. 238,000,000 per vessel per tahun. Nilai ekonomi non-ekstraktif merupakan nilai wisata dan ekosistem, meliputi kegiatan diving, transportasi dan taxi air. Kegiatan diving memberikan manfaat ekonomi tertinggi sekitar Rp. 300,000,000 per tahun, taxi air Rp. 90,000,000/tahun dan nilai ekonomi dari sewa kapal sebesar Rp. $75,000,000 /$ tahun.

\section{KESIMPULAN}

1. Penetapan G.Sulat-G. Lawang sebagai TWP sesuai kriteria kesesuaian ekologis, ekonomis dan sosial, namun pembagian sub zona berdasarkan kesesuaian ekologis tanpa pertimbangan kriteria ekonomi dan sosial. Hasil kesesuaian zonasi menunjukkan luas 
TWP Gili Sulat-Gili Lawang 10.000 hektar dengan kesesuaian zonasi 193.83 hektar sesuai zona inti, 143.33 hektar terdiri dari 108 hektar ekosistem terumbu karang dan 35.43 hektar ekosistem lamun sesuai untuk zona pemanfaatan terbatas, dan 9,666.47 hektar sesuai untuk zona lainnya yang terdiri dari zona rehabilitasi terumbu karang seluas 93.11 hektar, zona perlindungan 93.11 hektar dan perairan lain 8,585.76 hektar.

2. Analisis kesesuaian kawasan luas lahan yang sesuai untuk perikanan karang dan wisata selam 75.6 ha, wisata mangrove 23.40 hektar dan untuk zona rehabilitasi 93.11 ha (untuk snorkeling).

3. Analisis Daya Dukung Kawasan luasan terumbu karang untuk wisata selam 10,8 ha, jumlah kunjungan 3.956 orang per thn, wisata mangrove 23.40 ha, jumlah kunjungan 12,512 orang per tahun, perikanan karang 75.6 ha, produksi 16.64 ton/thn,

4. Pengelolaan TWP Gili Sulat-Gili Lawang berdasarkan kondisi eksisting adalah Kegiatan ekowisata belum optimal. Jumlah kunjungan 782 orang per tahun (di bawah daya dukung), karena kurang promosi dan infrastruktur pendukung terbatas, serapan tenaga kerja rendah, masyarakat belum merasakan manfaat ekowisata. Kegiatan perikanan karang dilakukan diseluruh areal terumbu karang (termasuk zona inti), Rata-rata tangkapan 17.4 ton per tahun sedangkan daya dukung perikanan karang sebesar 16.64 ton pertahun.

5. Analisis optimasi: dengan pengelolaan optimum (pemanfaatan sesuai daya dukung) berdampak pada meningkatnya penerimaan masyarakat tanpa menurunkan nilai ekosistem dalam kawasan, sehingga pengelolaan TWP G. Sulat-G. Lawang dapat berkelanjutan. Atribut penting yang perlu dioptimalkan dalam pengelolaan G. Sulat-G. Lawang adalah rehabilitasi sumberdaya (mangrove, terumbu karang dan lamun), peningkatan infrastruktur penunjang wisata.

6. Optimasi pengelolaan Kawasan Konservasi dapat dicapai dengan mengintegrasikan keempat dimensi pengelolaan melalui Keterpaduan program konservasi(terumbu karang dan mangrove), pengembangan budidaya laut, peningkatan partisipasi masyarakat, peningkatan teknologi penunjang kegiatan serta infrastruktur yang memadai, termasuk keterpaduan lintas sektor (kehutanan, kelautan dan perikanan), pariwisata, BPMPD, dan instansi terkait lainnya.

\section{DAFTAR PUSTAKA}

Arkham, MN., Adrianto, L., Wardiatno, Y., 2015. The Study of Seagrass Ecosystem and Small-Scale Fisheries Linkages (Case Studie: Malang Rapat and Berakit village, Bintan Regency, Riau Islands). Jurnal Sosek KP, 10 (2): 137-148(in Indonesian).

Balai Konservasi Sumberdaya Alam NTB, 2006. Laporan Hasil Inventarisasi Flora Fauna di Kawasan Konservasi Nusa Tenggara Barat.

Bengen DG..2002. Pengembangan Konsep Daya Dukung Dalam Pengelolaan Lingkungan

Pulau-Pulau Kecil. Kantor Kementrian Lingkungan Hidup RI dan Fakultas Perikanan dan Kelautan Institut Pertanian Bogor. 
Bengen DG. 2000. Sinopsis Teknik Pengambilan Contoh dan Analisis Data Biofisik Sumberdaya Pesisir. PKSPL FPIK-IPB.

Bengen DG..2002. Pengembangan Konsep Daya Dukung Dalam Pengelolaan Lingkungan

Pulau-Pulau Kecil. Kantor Kementrian Lingkungan Hidup RI dan Fakultas Perikanan dan Kelautan Institut Pertanian Bogor.

Bengen, DG, 2002. Sinopsis Ekosistem Sumberdaya Alam Pesisir dan Laut serta Prinsip Pengelolaannya. Pusat Kajian Sumberdaya Pesisir dan Laut (PKSPL) IPB Bogor.

Balai Riset Kepulauan dan Perikanan, 2004. Dokumen Rencana Pengelolaan Kawasan Konservasi laut Daerah Gili Sulat dan Gili Lawang kabupaten Lombok Timur.

Chua, T.E. and L.R. Garces (eds.) 1992 Waste management in the coastal areas of the ASEAN region, roles of governments, banking institutions, donor agencies, private sector and communities. Conference on Waste Management in the Coastal Areas of the ASEAN Region, Singapore, 28-30 June 1991. ASEAN/US Coastal Resources Management Project conference proceedings, 10. (33):218p.

Derrin Davis ClemTisdell, 1996. Economic Management of Recreational Scuba Diving and the Environment. Journal of Environmental Management, Volume 48, Issue 3, November 1996, Pages 229-248

Departemen Kelautan dan Perikanan RI, 2001. Pedoman Umum Pengelolaan Pulau-Pulau Kecil yang Berkelanjutan dan Berbasis Masyarakat. Ditjen Pesisir dan Pulau-Pulau Kecil. Jakarta. 21 hal

Departemen Kelautan dan Perikanan RI, 2002. Pedoman umum perencanaan pengelolaan pesisir. Departemen Kelautan dan Perikanan, Jakarta

Kementerian Lingkungan Hidup dan FPIK IPB. 2005. Laporan Akhir: Pengembangan Konsep daya Dukung Dalam Pengelolaan Lingkungan Pulau-Pulau Kecil. Bogor: Kementerian Lingkungan Hidup kerjsama dengan Fakultas Perikanan dan Ilmu Kelautan IPB.

Larkum, AWD., Comb, AJMc., Shepherd, SA., 1989. Biology of Seagrass: A Treatise On The Biology Of Seagrasses With Special Reference To The Australian Religion in: Aquatic Plant Studies 2. Elsevier. Amsterdam.

Maanema, M. 2003. Model Pemanfaatan Pulau-Pulau Kecil (Studi Kasus di Gugus Pulau Pari Kepulauan Seribu). Disertasi Doktor Sekolah Pascasarjan Institut Pertanian Bogor, Bogor.

Ochieng, C, A Phongsuwan, N \& Erftemeijer P, L, A. 1997. Assessment of the Current Status of Three Selected Coral Reefs in the Andaman Sea, Thailand. Wetlands International -Asia Pacific, Hat Yai, Publication No.1

Undang-undang Republik Indonesia Nomor 5 Tahun 1990 tentang Konservasi Sumber daya Alam Hayati dan Ekosistemnya.

Undang-Undang Republik Indonesia Nomor 27 Tahun 2007 Tentang Pengelolaan Wilayah Pesisir dan Pulau-Pulau Kecil

Yulianda, F. 2007. Makalah Ekowisata Bahari Sebagai Alternatif Pemanfaatan Sumberdaya Pesisir Berbasis Konservasi. Seminar Sains Departemen Manajemen Sumberdaya Periran FPIK-IPB, 21 Februari, Bogor. 